\title{
Formation of biogenic amines in fillets and minced flesh of three freshwater fish species stored at $3{ }^{\circ} \mathrm{C}$ and $15^{\circ} \mathrm{C}$
}

\author{
Martin Křížek ${ }^{1}$, František Vácha ${ }^{2}$, Pavel Vejsada ${ }^{2}$, Tamara Pelikánová ${ }^{1}$ \\ ${ }^{1}$ Faculty of Agriculture, Department of Applied Chemistry, ${ }^{2}$ Faculty of Fisheries and Protection of Waters, \\ Institute of Aquaculture, University of South Bohemia, České Budějovice, Czech Republic
}

Received July 2, 2010

Accepted December 14, 2011

\begin{abstract}
The aim of the present study was to compare the dynamics of biogenic amines formation in three freshwater fish species, to compare the progress of chemical changes in filleted and minced flesh, to find correlations of such changes with sensory properties and to find possible quality indicators for selected fish species. Samples $(\mathrm{n}=156)$ of fish fillets and fish mince of common carp (Cyprinus carpio), rainbow trout (Oncorhynchus mykiss) and perch (Perca fluviatilis) were stored at $3{ }^{\circ} \mathrm{C}$ and $15^{\circ} \mathrm{C}$. The amines were determined as the $N$-substituted benzamides, after derivatization with benzoylchloride by micellar electrokinetic capillary chromatography. Based on the biogenic amine contents and sensory properties, the shelf life of samples at $3^{\circ} \mathrm{C}$ was $11-16$ days and 7-10 days for fillets and mince, respectively, and $2-3$ days at $15^{\circ} \mathrm{C}$ regardless of sample processing. Content of putrescine seems to be a good quality indicator for all examined fish species. The fish species and the method of flesh processing did not have a significant influence on the putrescine formation. Tyramine was formed mainly in carp and trout mince at $15{ }^{\circ} \mathrm{C}$. Samples of good and acceptable quality did not contain toxicologically significant concentrations of histamine or tyramine. Contrary to marine fish, information about biogenic amines contents in freshwater fish is scarce. Comparison of the dynamics of amines formation in fillets and processed fish flesh has not been studied yet. The progress of decomposition processes is compared based on dynamic models.
\end{abstract}

Putrescine, carp, trout, perch, quality indicator

Biogenic amines (BAs), namely putrescine (PUT), cadaverine (CAD), spermidine (SPD), spermine (SPM), histamine (HIM), tyramine (TYM) and tryptamine (TRM) are organic bases that occur not only in fish and fish products, but also in various other foods of proteinaceous origin. Accumulation of BAs in fish flesh is associated with continuing spoilage (Baixas-Nogueras et al. 2002). The reasons for amine determination in fish are twofold. The first is their potential toxicity; the second is the possibility of using them as food quality indicators (Kř́ižek et al. 2004). Risk of amines formation is high especially when the flesh is minced (Chen et al. 2008). Although numerous studies on the formation of amines in marine fish have been reported, only limited data are available on changes of BAs during spoilage of freshwater fish. For rainbow trout (Oncorhynchus mykiss), PUT, TYM, SPD and SPM were recommended as quality indicators (Chytiri et al. 2004). The contents of BAs correlated with the sensory rejection time for rainbow trout (Katikou et al. 2006) and for carp (Kř́ižek et al. 2002).

Common carp (Cyprinus carpio), rainbow trout and perch (Perca fluviatilis) are important freshwater fish rich in unsaturated fatty acids (Buchtová et al. 2007). In Europe all these species are very popular with anglers and their farm production is large. Fish mince is a prospective raw material for food industry. The aim of the present study was to compare the dynamics of BAs formation in three common freshwater fish species, to compare changes in BAs in filleted and minced flesh, to correlate such changes with sensory properties and to find possible quality indicators for selected fish species.

Address for correspondence:

prof. Ing. Martin Křižzek, CSc.

Faculty of Agriculture, Department of Applied Chemistry

University of South Bohemia

Studentská 13, CZ-37005 České Budějovice, Czech Republic

Phone: +420387772655

E-mail: krizek@zf.jcu.cz

http://www.vfu.cz/acta-vet/actavet.htm 


\section{Materials and Methods}

Fish production and processing

Fresh common carp (Cyprinus carpio) $(\mathrm{n}=7$; average weight: $1.5-2.5 \mathrm{~kg}$; length: $35-50 \mathrm{~cm}$; omnivorous, planktonofagous fish), rainbow trout (Oncorhynchus mykiss) $(\mathrm{n}=25 ; 0.25-0.35 \mathrm{~kg} ; 25-30 \mathrm{~cm}$; carnivorous, predatory fish) and perch (Perca fluviatilis) $(\mathrm{n}=25 ; 0.30-0.45 \mathrm{~kg} ; 25-30 \mathrm{~cm}$; carnivorous, predatory fish) were obtained from a fish farm in Vodňany near České Budějovice (Czech Republic). The fish were killed, gutted and their body was cut into two halves (a pair of fillets with backbones). The material was washed in drinking water. One half was used for fillets, the second half was processed in a fish meat drum separator to produce fish mince. Fillets were prepared from portions of about $100 \mathrm{~g}$ of muscles from the chest area of the fish. Fish mince was produced in the TR-6 meat separator (Nurle Oy, Helsinki, Finland). Fish samples $(n=156)$ were analyzed in duplicate. Samples were placed in HDPE (polyethylene) bags. Experiments were conducted at 3 and $15^{\circ} \mathrm{C}$. Fish flesh and fish mince samples $(\mathrm{n}=156)$ were analysed in parallel every $24 \mathrm{~h}$ of storage.

Analyses and sensory tests

Samples were homogenised in a commercial food hand-blender (Philips, Vienna, Austria). Biogenic amines were extracted from $40 \mathrm{~g}$ of homogenised flesh samples with diluted perchloric acid, p.a. (0.6 M). After filtration, the volume was made up to $150 \mathrm{ml}$ with perchloric acid. The amines were determined as the $N$-substituted benzamides, after derivatization with benzoylchloride by micellar electrokinetic capillary chromatography, using capillary zone electrophoresis machine. The procedure has been described in detail by Kř́žek and Pelikánová (1998). Analyses were carried out using a Spectraphoresis 2000, a fully automated system for capillary zone electrophoresis equipped with a multi-wavelength UV-VIS scanning detector (Thermo Separation Products, Fremont, CA, USA). Sensory tests, carried out by five trained panelists, were complementary to the main objective of the study, the determination of chemical changes in the flesh matrix and were simplified to three levels: good (1), acceptable (2) and poor (3). The organoleptic properties were based mainly on odour and general appearance. Levels of odour: 1 (meaty), 2 (slightly spicy), 3 (fishy, repulsive). Levels of general appearance (colour/texture): 1 (white/tightly elastic), 2 (greyish/solid), 3 (grey/muddy).

\section{Statistical evaluation}

Samples were prepared in parallel and each sample was analysed twice. Fitting of curves, describing the kinetics of amine formation, was done by the mathematical software Maple V v. 5.0 (Waterloo Maple Inc., Waterloo, Canada). Correlation coefficients were calculated as Spearman-Rank correlation type (Multivariate analysis, correlation matrix). Analysis of variance (ANOVA) was calculated by General linear models, Up to 1-way model type. These and other statistics were calculated using NCSS 2007 (NCSS, LLC., Kaysville, UT, USA).

\section{Results and Discussion}

Mean contents of all amine concentrations, for all sampling days and sensory scores, are shown in Tables 1-4. Relative standard deviations of the results were $\pm 7-10 \%$. Due to the the large extent of tables, individual values of RSDs are not shown. Experiments were designed as dynamic. Contents of PUT, CAD, HIM and TYM increased with time, SPD showed very slight decrease in carp and perch samples. Sensory properties were highly correlated especially with PUT and CAD in all samples (Table 5). A mutual relationship between sensory score and HIM and TYM was not significant, contrary to our experiments with vacuum-packed carp flesh (Křížek et al. 2004). These and previous results (Kř́ižek et al. 2002) reveal the applicability of PUT or CAD as the quality criterion not only for carp flesh, but also for trout and perch flesh. Cadaverine and HIM are sometimes formed belatedly, compared to sensory signals, which was also observed by Chytiri et al. (2004) in trout samples. Different fish species might reach different BA levels at the sensory rejection time. Information is still lacking. Ozogul et al. (2006) found, that samples of European eel (Anguilla anguilla) at the sensory rejection level contained 46-88 mg PUT/kg. For red mullet (Mullus barbatus) PUT content exceeding $10 \mathrm{mg} / \mathrm{kg}$ was associated with poor quality samples (Ozyurt et al. 2009). Similar value of $13-14 \mathrm{mg} / \mathrm{kg}$ was found by Chytiri et al. (2004) studying rainbow trout. Supposing that $15 \mathrm{mg}$ PUT/kg represents a critical concentration (Kř́ižek et al. 2002), we tried to find the respective critical times (days), when the given concentration had been reached.

As the kinetic curves of PUT formation usually show a smooth increase, they can be described by regression equations (Křížek et al. 2004; Baixas-Nogueras et al. 2005). By solving these equations for the proposed critical concentration 


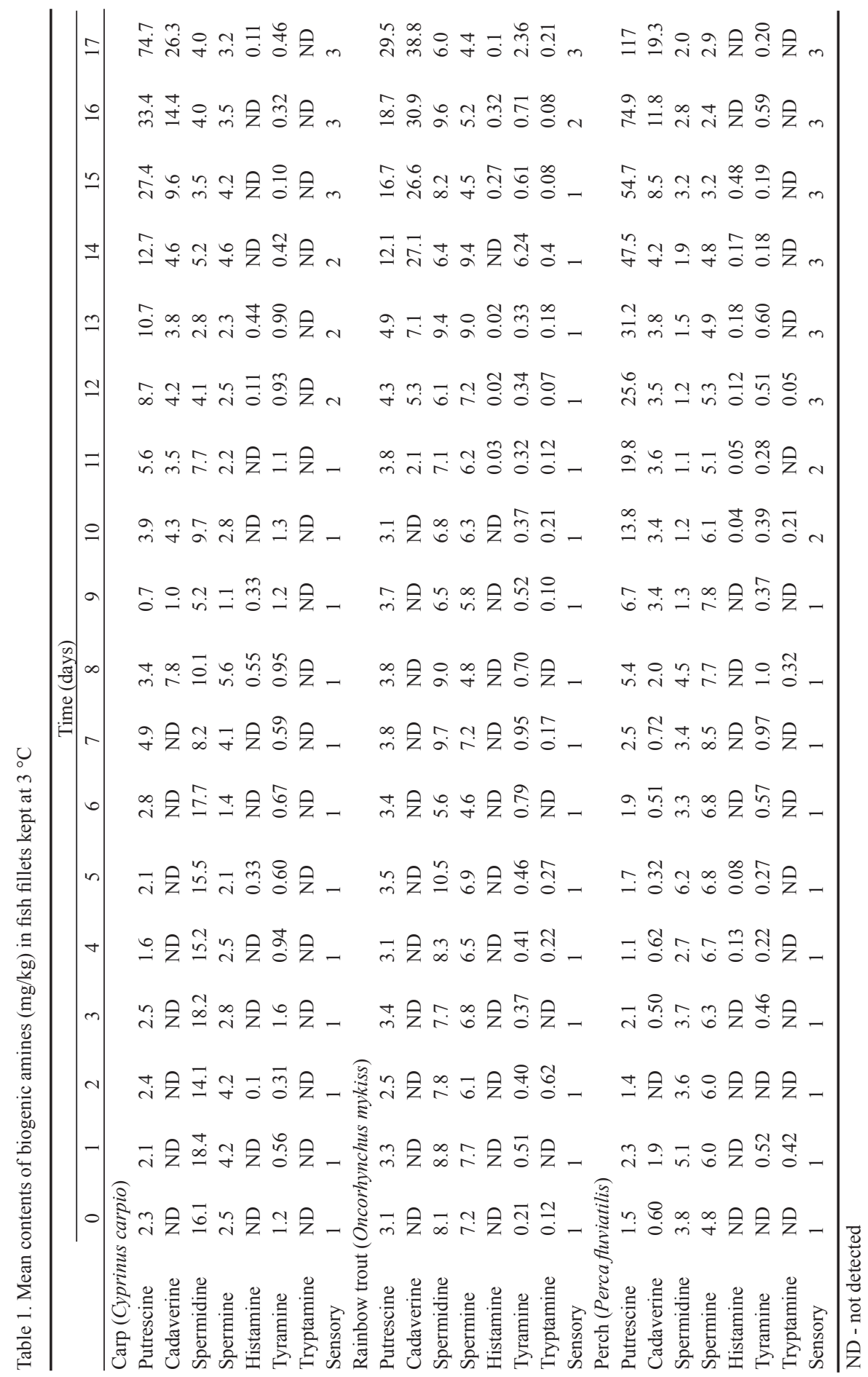




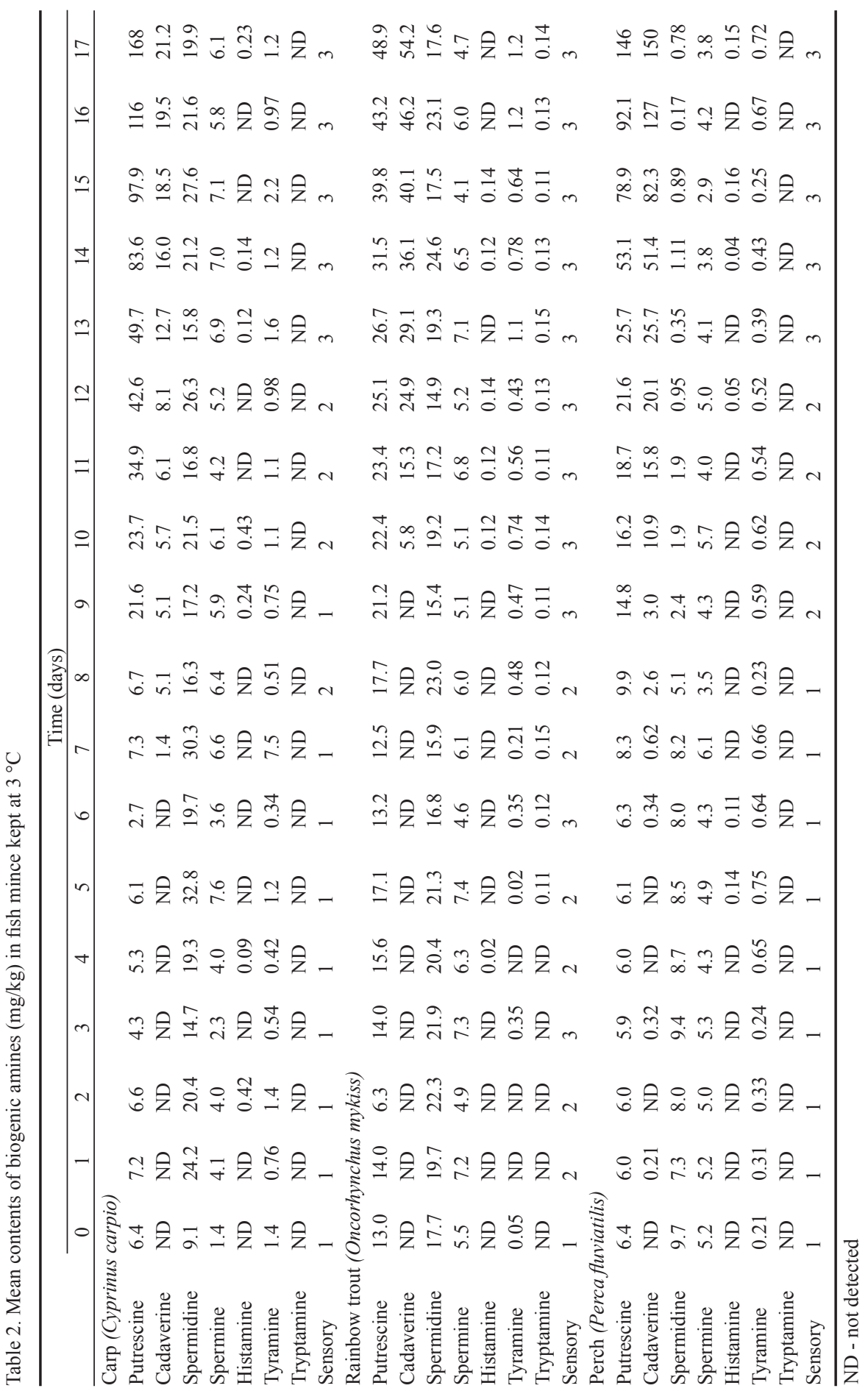


Table 3. Mean contents of biogenic amines $(\mathrm{mg} / \mathrm{kg})$ in fish fillets kept at $15^{\circ} \mathrm{C}$

\begin{tabular}{|c|c|c|c|c|c|c|c|c|}
\hline \multicolumn{9}{|c|}{ Time (days) } \\
\hline & 0 & 1 & 2 & 3 & 4 & 5 & 6 & 7 \\
\hline \multicolumn{9}{|c|}{ Carp (Cyprinus carpio) } \\
\hline Putrescine & 2.3 & 2.0 & 5.8 & 37.3 & 61.0 & 117 & 213 & 236 \\
\hline Cadaverine & ND & 0.71 & 4.4 & 33.0 & 55.3 & 152 & 310 & 473 \\
\hline Spermidine & 19.4 & 22.8 & 16.6 & 6.9 & 6.8 & 4.6 & 5.1 & 2.9 \\
\hline Spermine & 3.0 & 3.3 & 2.6 & 4.9 & 4.6 & 3.4 & 4.5 & 4.4 \\
\hline Histamine & ND & 0.26 & 0.18 & 2.1 & 26.0 & 30.9 & 35.5 & 38.6 \\
\hline Tyramine & 0.05 & 0.41 & ND & 3.4 & 15.5 & 40.9 & 74.1 & 74.7 \\
\hline Tryptamine & ND & 0.48 & ND & ND & 0.91 & 1.7 & 4.6 & 7.5 \\
\hline Sensory & 1 & 1 & 1 & 3 & 3 & 3 & 3 & 3 \\
\hline \multicolumn{9}{|c|}{ Rainbow trout (Oncorhynchus mykiss) } \\
\hline Putrescine & 3.1 & 3.4 & 4.3 & 19.0 & 70.0 & 126 & 212 & 330 \\
\hline Cadaverine & ND & 0.11 & 22.4 & 72.9 & 84.5 & 99.9 & 101 & 129 \\
\hline Spermidine & 8.2 & 8.1 & 10.0 & 7.4 & 1.7 & 2.6 & 1.5 & 1.5 \\
\hline Spermine & 6.0 & 6.2 & 8.4 & 8.7 & 7.6 & 5.0 & 4.9 & 4.6 \\
\hline Histamine & ND & ND & ND & 9.9 & 50.7 & 62.8 & 64.4 & 79.7 \\
\hline Tyramine & ND & ND & ND & 7.8 & 8.2 & 38.0 & 43.9 & 99.6 \\
\hline Tryptamine & ND & 0.13 & 0.35 & 0.58 & ND & ND & ND & ND \\
\hline Sensory & 1 & 1 & 1 & 2 & 3 & 3 & 3 & 3 \\
\hline \multicolumn{9}{|c|}{ Perch (Perca fluviatilis) } \\
\hline Putrescine & 6.4 & 7.6 & 33.7 & 46.7 & 52.5 & 71.2 & 99.6 & 130 \\
\hline Cadaverine & 0.61 & 1.2 & 15.9 & 19.2 & 22.1 & 22.5 & 25.6 & 33.4 \\
\hline Spermidine & 3.9 & 4.6 & 2.5 & 1.1 & 1.1 & 0.79 & 0.44 & 0.13 \\
\hline Spermine & 7.4 & 7.3 & 4.2 & 4.3 & 4.3 & 5.5 & 3.5 & 3.9 \\
\hline Histamine & $\mathrm{ND}$ & 0.14 & 0.22 & 4.64 & 46.0 & 53.8 & 63.3 & 110 \\
\hline Tyramine & ND & ND & 0.15 & 0.10 & 2.3 & 33.6 & 58.6 & 79.0 \\
\hline Tryptamine & ND & ND & 1.3 & ND & ND & ND & ND & $\mathrm{ND}$ \\
\hline Sensory & 1 & 1 & 2 & 3 & 3 & 3 & 3 & 3 \\
\hline
\end{tabular}

ND - not detected

$(15 \mathrm{mg} / \mathrm{kg}$ ), we obtained estimates of the respective critical times (days). Table 6 shows calculated critical days of storage (CCD) of fish flesh when a given PUT level $(15 \mathrm{mg} / \mathrm{kg})$ can be expected. CCD are estimated by solving the equation PUT = $\left(\mathrm{A}+\mathrm{B}^{*}\right.$ Time $) /\left(1+\mathrm{C}^{*}\right.$ Time $)$ which fits best the dynamics of PUT formation (for regression correlation coefficients see Table 6). It is seen that the critical content of PUT was reached in 11-15 days in filleted flesh kept at $3{ }^{\circ} \mathrm{C}$ and in $6-10$ days in fish mince. At $15{ }^{\circ} \mathrm{C}$ the differences between fillets and mince were not so pronounced, but higher temperature shortened this time to 2-3 days. Typical sensory score for given PUT level $(15 \mathrm{mg} / \mathrm{kg})$ was $1-2$. At $15^{\circ} \mathrm{C}$ the difference in the CCD (fillets, mince) was not so marked, compared to samples kept at $3{ }^{\circ} \mathrm{C}$, probably due to the dominant deleterious effect of the temperature.

These results raised the question whether the differences among the $\mathrm{CCD}$ are significant. Three factors for the ANOVA tests were selected: fish species (A), the manner of sample processing (B) and the temperature $(\mathrm{C})$. The results were as follows. Factor $\mathrm{A}: \mathrm{F}=0.13, P$ $=0.884(P>>0.05)$; Factor $\mathrm{B}: \mathrm{F}=5.13, P=0.058(P>0.05)$ and Factor $\mathrm{C}: \mathrm{F}=38.40, P$ $=0.00045(P<<0.001)$.

It can be summarized that the content of PUT seems to be a good quality indicator not only for carp (Kř́žzek et al. 2002), but also for trout and perch. For this purpose 
Table 4. Mean contents of biogenic amines $(\mathrm{mg} / \mathrm{kg})$ in fish mince kept at $15^{\circ} \mathrm{C}$

\begin{tabular}{|c|c|c|c|c|c|c|c|c|}
\hline \multicolumn{9}{|c|}{ Time (days) } \\
\hline & 0 & 1 & 2 & 3 & 4 & 5 & 6 & 7 \\
\hline \multicolumn{9}{|c|}{ Carp (Cyprinus carpio) } \\
\hline Putrescine & 6.4 & 5.6 & 43.1 & 62.1 & 108 & 175 & 186 & 228 \\
\hline Cadaverine & ND & 0.53 & 86.7 & 89.4 & 114 & 139 & 172 & 242 \\
\hline Spermidine & 9.0 & 16.5 & 17.6 & 12.0 & 11.0 & 9.0 & 1.8 & 2.2 \\
\hline Spermine & 3.2 & 3.3 & 4.6 & 4.2 & 4.8 & 6.1 & 2.7 & 2.8 \\
\hline Histamine & ND & ND & 0.23 & 0.91 & 2.6 & 15.3 & 22.8 & 33.1 \\
\hline Tyramine & 0.05 & ND & 5.46 & 3.3 & 14.6 & 54.7 & 74.9 & 78.7 \\
\hline Tryptamine & ND & ND & 2.0 & ND & ND & 0.97 & ND & ND \\
\hline Sensory & 1 & 3 & 3 & 3 & 3 & 3 & 3 & 3 \\
\hline \multicolumn{9}{|c|}{ Rainbow trout (Oncorhynchus mykiss) } \\
\hline Putrescine & 13.0 & 15.9 & 20.1 & 56.1 & 92.3 & 144 & 261 & 398 \\
\hline Cadaverine & ND & ND & ND & 36.1 & 144 & 280 & 485 & 839 \\
\hline Spermidine & 8.1 & 21.9 & 18.5 & 12.0 & 8.6 & 8.5 & 4.3 & 3.7 \\
\hline Spermine & 5.5 & 7.1 & 3.5 & 4.7 & 6.2 & 5.0 & 3.9 & 5.8 \\
\hline Histamine & ND & ND & ND & 0.41 & 6.6 & 22.5 & 31.5 & 34.1 \\
\hline Tyramine & ND & 0.09 & 0.25 & 7.3 & 7.3 & 33.9 & 51.8 & 86.5 \\
\hline Tryptamine & ND & ND & ND & 0.38 & 0.38 & 1.0 & 6.2 & 12.2 \\
\hline Sensory & 2 & 2 & 2 & 3 & 3 & 3 & 3 & 3 \\
\hline \multicolumn{9}{|c|}{ Perch (Perca fluviatilis) } \\
\hline Putrescine & 1.5 & 2.1 & 26.5 & 84.8 & 203 & 253 & 342 & 419 \\
\hline Cadaverine & ND & 1.8 & 27.0 & 98.6 & 229 & 316 & 457 & 552 \\
\hline Spermidine & 8.7 & 5.7 & 5.3 & 1.6 & 2.1 & 2.6 & 2.6 & 2.5 \\
\hline Spermine & 5.2 & 5.4 & 4.4 & 3.5 & 4.2 & 3.2 & 2.9 & 2.6 \\
\hline Histamine & ND & ND & 0.26 & 1.9 & 10.0 & 34.6 & 35.8 & 36.1 \\
\hline Tyramine & ND & ND & 0.81 & 0.55 & 0.75 & 0.17 & ND & ND \\
\hline Tryptamine & ND & ND & 0.65 & ND & ND & ND & 0.41 & ND \\
\hline Sensory & 1 & 1 & 3 & 3 & 3 & 3 & 3 & 3 \\
\hline
\end{tabular}

ND - not detected

CAD can be alternatively used, because both these amines were in the best correlation with sensory levels. Histamine and TYM were formed preferentially in samples at $15^{\circ} \mathrm{C}$ and thus their occurrence may signal improper temperature conditions. The CAD, HIM and TYM sometimes showed a slight delay in their formation compared to sensory signals. According to the calculated critical days for the PUT content it was found that all the three fish species do not significantly differ in their susceptibility to spoilage. The mincing accelerated the spoilage especially in samples stored at $15^{\circ} \mathrm{C}$. Fish fillets and fish mince stored at $15{ }^{\circ} \mathrm{C}$ showed signs of decay in chemical and in organoleptic indicators in 2 days, fish mince stored at $3{ }^{\circ} \mathrm{C}$ in about 8 days, fish fillets stored at $3{ }^{\circ} \mathrm{C}$ in about 14 days. Samples of fish flesh and fish mince did not contain toxicologically significant concentrations of HIM or TYM, provided the sensory score of the samples was less than 3 .

\section{Acknowledgements}

The work was supported by the projects MSM 6007665806 from the Czech Ministry of Education, GAČR P 503/11/1417, CENAKVA CZ.1.05/2.1.00/01.0024 and QH71011 NAZV from the Czech Ministry of Agriculture. 
Table 5. Spearman correlation coefficients among amines and fish quality sensory score (samples kept at $3{ }^{\circ} \mathrm{C}$ )

\begin{tabular}{|c|c|c|c|c|c|c|}
\hline & PUT & CAD & HIM & TYM & SPD & SPM \\
\hline Carp/ Fillets & $0.835 * * *$ & $0.764 * * *$ & NS & NS & $-0.813 * * *$ & NS \\
\hline Carp/ Mince & $0.876^{* * *}$ & $0.932 * * *$ & NS & NS & NS & $0.535^{*}$ \\
\hline Trout/ Fillets & $0.546^{*}$ & $0.621 * *$ & $0.603 * *$ & NS & NS & NS \\
\hline Trout/ Mince & $0.698 * *$ & $0.665 * *$ & NS & $0.745 * * *$ & NS & NS \\
\hline Perch/ Fillets & $0.890 * * *$ & $0.882 * * *$ & $0.505^{*}$ & NS & $-0.626^{* *}$ & $-0.779 * * *$ \\
\hline Perch/Mince & $0.919 * * *$ & $0.924 * * *$ & NS & NS & $-0.910 * * *$ & $-0.528 *$ \\
\hline
\end{tabular}

NS - not significant, PUT - putrescine, CAD - cadaverine, HIM - histamine, TYM - tyramine, SPD - spermidine, SPM - spermine

$* P \leq 0.05, * * P \leq 0.01, * * * P \leq 0.001$

Table 6. Calculated critical days of storage of fish flesh when a given putrescine level $(15 \mathrm{mg} / \mathrm{kg})$ can be expected

\begin{tabular}{lccc}
\hline & Calculated critical days & r & Sensory score \\
\hline Carp/ Fillets/ $3{ }^{\circ} \mathrm{C}$ & 15.0 & 0.993 & 2 \\
Trout/ Fillets/ $3{ }^{\circ} \mathrm{C}$ & 16.4 & 0.974 & 1 \\
Perch/ Fillets/ $3{ }^{\circ} \mathrm{C}$ & 11.0 & 0.995 & 2 \\
Carp/ Mince/ $3{ }^{\circ} \mathrm{C}$ & 8.2 & 0.990 & 1 \\
Trout/ Mince/ $3{ }^{\circ} \mathrm{C}$ & 6.4 & 0.978 & 2 \\
Perch/ Mince/ $3{ }^{\circ} \mathrm{C}$ & 9.8 & 0.989 & 2 \\
Carp/ Fillets/ $15{ }^{\circ} \mathrm{C}$ & 2.7 & 0.978 & 2 \\
Trout/ Fillets/ $15^{\circ} \mathrm{C}$ & 2.9 & 0.994 & 1 \\
Perch/ Fillets/ $15^{\circ} \mathrm{C}$ & 2.0 & 0.993 & 1 \\
Carp/ Mince/ $15{ }^{\circ} \mathrm{C}$ & 1.9 & 0.986 & 3 \\
Trout/ Mince/ $15^{\circ} \mathrm{C}$ & 2.1 & 0.996 & 2 \\
Perch/ Mince/ $15^{\circ} \mathrm{C}$ & 2.1 & 0.989 & 2 \\
\hline
\end{tabular}

$\mathrm{r}$ - regression correlation coefficient, Sensory score - means sensory score observed

at calculated time (1 - good, 2 - acceptable, 3 - poor $)$

\section{References}

Baixas-Nogueras S, Bover-Cid S, Veciana-Nogues T, Vidal-Carou MC 2002: Chemical and sensory changes in Mediterranean hake (Merluccius merluccius) under refrigeration (6-8 degrees C) and stored in ice. J Agric Food Chem 50: 6504-6510

Baixas-Nogueras S, Bover-Cid S, Veciana-Nogues MT, Marine-Font A, Vidal-Carou MC 2005: Biogenic amine index for freshness evaluation in iced Mediterranean hake (Merluccius merluccius). J Food Prot 68: 2433-2438

Buchtová H, Svobodová Z, Křížek M, Vácha F, Kocour M, Velíšek J 2007: Fatty acid composition in intramuscular lipids of experimental scaly crossbreds in 3-year-old common carp (Cyprinus carpio L.). Acta Vet BRNO 76: S73-S81

Chen HC, Kung HF, Chen WC, Lin WF, Hwang DF, Lee YC, Tsai YH 2008: Determination of histamine and histamine-forming bacteria in tuna dumpling implicated in a food-borne poisoning. Food Chem 106: 612-618

Chytiri S, Paleologos E, Savvaidis I, Kontominas MG 2004: Relation of biogenic amines with microbial and sensory changes of whole and filleted freshwater rainbow trout (Onchorynchus mykiss) stored on ice. J Food Prot 67: 960-965

Katikou P, Georgantelis D, Paleologos EK, Ambrosiadis I, Kontominas MG 2006: Relation of biogenic amines' formation with microbiological and sensory attributes in Lactobacillus-inoculated vacuum-packed rainbow trout (Oncorhynchus mykiss) fillets. J Agric Food Chem 54: 4277-4283

Křížek M, Pelikánová T 1998: Determination of seven biogenic amines in foods by micellar electrokinetic capillary chromatography. J Chromatogr A 815: 243-250 
Křížek M, Pavlíček T, Vácha F 2002: Formation of selected biogenic amines in carp meat. J Sci Food Agric 82: 1088-1093

Křŕžek M, Vácha F, Vorlová L, Lukášová J, Cupáková S 2004: Biogenic amines in vacuum-packed and nonvacuum-packed flesh of carp (Cyprinus carpio) stored at different temperatures. Food Chem 88: 185-191

Ozogul Y, Ozogul F, Gokbulut C 2006: Quality assessment of wild European eel (Anguilla anguilla) stored in ice. Food Chem 95: 458-465

Ozyurt G, Kuley E, Ozkutuk S, Ozogul F 2009: Sensory, microbiological and chemical assessment of the freshness of red mullet (Mullus barbatus) and goldband goatfish (Upeneus moluccensis) during storage in ice. Food Chem 114: 505-510 DOI: 10.1016/j.foodchem.2008.09.078 